\title{
Key issues and trends in the water policy literature
}

\author{
Jonathan Chenoweth \\ Centre for Environmental Strategy, University of Surrey, Guildford, Surrey, GU2 7XH, UK. \\ Email: j.chenoweth@surrey.ac.uk
}

\begin{abstract}
:
Content analysis of two complete years of articles published in the journal Water Policy show a wide spread of issues dominate the policy analysis discourse, with citations of the articles being spread across the thematic issues published. Few articles in the journal were particularly technical in nature but rather the journal has tended to published articles which are more directly linked to water policy. Articles related broadly to institutional and regulatory reform were numerically the most significant in terms of the published content of the journal. Examination of the short-term citation rate of articles published did not show a significant bias towards any thematic issue covered by the journal, suggesting broad interest in the wide range of topics relating to water policy issues.
\end{abstract}

Keywords: water policy, content analysis, academic discourse

\section{Introduction}

Effective water resources management is key to the functioning and development of all human societies, with decisions about how water resources are managed being set through policy. Good water policy can help ensure that water is used to the maximum benefit of human society and the natural environment.

According to Schad (1991) national water policy as a concept is difficult to define in part because the word "policy" is difficult to define. The definition of the word "policy" given in the Oxford English Dictionary appropriate to the context of water policy is "[a] principle or course of action adopted or proposed as desirable, advantageous, or expedient" (OED Online 2011). Water policy refers to strategic decision making and the choosing of processes for managing the water sector and its individual components. Given the potentially strategic nature of policy making, trends in policy making can reveal the future direction in which the water sector as a whole is moving.

Since its first publication in 1999 by the World Water Council and the International Water Association, the journal Water Policy has been a significant forum for the publication of research in the field of water policy, seeking to provide a forum for dialogue and debate between the different water management communities, including those focused upon industrial, urban, agricultural water supply. It aims to publish analyses, reviews and debates on all aspects relating to water resources management without geographic bias to developed or developing nations; its editors are drawn from four continents. It is a refereed journal with an acceptance rate on paper submitted during the 2007-12 period of 27 percent (Delli-Priscoli, personal communication, August 2, 2012), thus is selective in terms of the quality of its published articles. As such, it provides a relatively representative sample of academic discourse in the somewhat difficult to define field of water policy.

Based upon a content analysis census of articles recently published in Water Policy this paper examines what issues dominant in the journal at present and thus this article seeks to identify current trends in the water policy discourse and the discipline of water resources management more broadly. 


\section{Methodology}

Content analysis as a research methodology was developed in the US in early twentieth century as a means of analysing the balance content of published media (Gillham 2005). Content analysis looks for the presence of concepts in a text, condensing potentially many concepts into fewer broad categories as a means of discovering patterns in the analysed media and thus to better understand the underlying phenomena (Matthews and Ross 2010). While in its earliest forms content analysis focused counting the frequency of the occurrence of particular words, the technique has been extended to consider context and meanings as well.

This paper uses content analysis to identify leading issues and trends in the field of water policy, as published in the journal Water Policy. All articles published in the journal in 2010 and 2011 were examined, with each year analysed separately in order to identify inter-annual variation as well as any short term trends. While a longer time frame could have been selected for the analysis, since the aim is to identify current trends in the discipline, it was thought that focusing upon the most recent complete published years was more appropriate while ensuring that the volume of text content requiring analysis remained manageable.

Quantitative content analysis was used examine the frequency of word usage in the abstracts and the keywords specified by article authors for each article published in Water Policy. These frequency counts were used to prepare tag clouds which provide a visual representation of the relative frequency of key word usage. Tag clouds, also referred to as word clouds, show a visually weighted representation of text data by displaying in a tag diagram the words which occur most frequently in a larger font size or brighter colour (Steinbock, R et al. 2007). Tag clouds allow for the easy highlighting of the most important content of the inputted text from the overall content of the text (Deutsch, Schrammel et al. 2011). While spatial organisation of the tag cloud content can vary depending upon the software used to prepare the tag cloud, words within a cloud are most typically arranged in alphabetical order.

A number of tag cloud generators are available which varying in terms of how the text data can be inputted as well as their flexibility in terms of how they display the resulting word cloud. In this paper the tag cloud generator developed by Steinbock (2006) was used. This generator was set to ignore common words used in English, thus words such as "the" or "and" will not appear in the cloud, nor will "water" since this water was so dominant in the text data and thus the generator was set to exclude it. Similar words were grouped by the generator, thus, "teach", "teachers" and "teaching" would all be combined if they occurred frequently in the text (Steinbock 2006). The number of words appearing in the cloud can be selected by the user. In this study, a tag cloud of 25 words was generated from the combined keywords specified by the authors all published articles of Water Policy over a one year period, and a tag cloud of 50 words was generated from the combined abstract texts of all published articles over the same year. Thus, two tag clouds were produced for each of 2010 and 2011.

Content analysis was used in a more qualitative form by grouping published article into themes. Initially it was intended to use the topics listed on the Water Policy journal website as those covered by the journal for the thematic groupings. However, some of these topics are ambiguous or overlapping, and an initial grouping of articles into these themes showed that some articles fitted equally well into more than one group while others did not really fit into any. Similarly some topics appeared to included few, if any, articles. Therefore, modified themes based upon the published content of journal were used instead. Each published article was then allocated to one of these thematic groupings, with the dominant theme expressed in the article's abstract used to as the deciding factor if the article potentially could have fitted into more than one group. The number of articles allocated to each theme was used to show the relative prominence of that issue at present in the Water Policy journal and water policy academic discourse more generally. 
The number of citations received by papers in each theme was used as an additional check to identify the leading themes in water policy since, while the number of articles published on an issue provides some indication of how topical the issue is, it will not alone show the degree of interest of the wider water resources management community in that issue. The ISI Web of Knowledge database was used at the beginning of January 2012 to check which papers published in the preceding two years had received citations in the academic literature.

\section{Results}

\subsection{Word Clouds}

Figures 1 and 2 show the tag clouds generated from the stated key words of all articles published in Water Policy in 2010 and 2011 respectively. Figures 3 and 4 show the tag clouds generated from the abstracts of all articles published in Water Policy in 2010 and 2011 respectively. All four tag clouds feature the "management" very prominently, which is perhaps unsurprising given that water policy is about water management. More interestingly though, the word "policy" varied significantly in its prominence. For the tag clouds relating to 2010, "policy" occurred at a sufficiently low frequency that it was only just included in the top 25 or 50 word selected for these tag clouds whereas in 2011 it was a significant key word, suggesting that the papers published in the journal in 2011 were more overtly in keeping with the journals aims. In 2010, "development", "reform", "regulation", "resources" and "sanitation" all occurred prominently in the keywords tag cloud but not in 2011, whereas "governance", "pollution", "public", "rights", and "utilities" were significant keywords in 2011 but not in 2010. Similar variation can be seen between the tag clouds generated from the article abstracts.

\subsection{Thematic issues coverage}

All papers published in Water Policy in 2010 and 2011 were analysed for their dominant theme and on the basis of this qualitative content analysis, papers were grouped into the thematic groupings shown in Table 1, which also shows the number of articles in each theme in each year.

Table 1: Thematic breakdown of articles published in Water Policy during 2010 and 2011.

\begin{tabular}{|l|l|l|}
\hline Theme / issue & $\begin{array}{l}\text { Number of } \\
\text { articles } \\
\text { published in } \\
\mathbf{2 0 1 0}\end{array}$ & $\begin{array}{l}\text { Number of } \\
\text { articles } \\
\text { published } \\
\text { in 2011 }\end{array}$ \\
\hline Transboundary water issues & 8 & 3 \\
\hline Urban water utilities and asset management & 5 & 7 \\
\hline Public perceptions and preferences for water services & 3 & 4 \\
\hline $\begin{array}{l}\text { Integrated water resources management / river basin management } \\
\text { / EU Water Framework Directive }\end{array}$ & 8 & 5 \\
\hline Adaptation to water scarcity & 9 & 7 \\
\hline Improving access to water supply and sanitation & 10 & 5 \\
\hline Agricultural water issues & 8 & 11 \\
\hline Pollution control / preservation of the natural environment & 6 & 4 \\
\hline Institutional or regulatory reform & 12 & 10 \\
\hline
\end{tabular}

\section{Transboundary water issues}

In 2010 there were eight articles published on transboundary water issues (Balthrop and Hossain 2010; Bearden 2010; Chowdhury 2010; De Stefano, Edwards et al. 2010; Easter and McCann 2010; Judkins and Larson 2010; Rieu-Clarke 2010; van de Watering and Neher 2010). Two of these articles had been cited by the end of 2011 - a review paper by Balthrop (2010) which looked globally at treaties and transboundary flooding and Chowdhury (2010) which looked primarily at water management in Bangladesh. No single geographic region dominated, with one paper relating to 
Europe, two to Asia, one to North America and four were not geographically specific. In 2011 only three articles were published on transboundary water issues (Alam, Dione et al. 2011; Bleser and Nelson 2011; Chenoweth 2011). None of these articles had been cited by elsewhere by the end of 2011; one article related to the Middle East, one to North America, and one to Europe and Africa. Thus, a range of transboundary case studies were examined during 2010 and 2011.

\section{Urban water utilities and asset management}

In 2010 there were five articles published on urban water utilities and asset management (AguilarBenitez and Saphores 2010; Kumar 2010; Palme 2010; van der Brugge and de Graaf 2010; Vinnari and Hukka 2010). Two papers considered benchmarking and the performance of water utilities (Aguilar-Benitez and Saphores 2010; Kumar 2010), and three looked at urban water systems sustainability and infrustructure renewal (van der Brugge and de Graaf 2010); Palme, 2010 \#32; Vinnari, 2010 \#38 \}, with one of these papers being cited elsewhere in the academic literature. In 2011 seven articles were published on this theme. Four articles (Berg and Marques 2011; Correia and Marques 2011; Ferro and Romero 2011; Picazo-Tadeo, Saez-Fernandez et al. 2011) related to benchmarking and performance of water utilities, with two of these receiving citations. Of the other articles in this thematic area, one article evaluated the operational status of wastewater treatment plants compared to official data on their status (Laspidou, Gialis et al. 2011) and two looked at strategic planning and development in the water sector (Dominguez, Truffer et al. 2011; Egerton, Santos et al. 2011), with none of these articles being cited by the end of 2011.

\section{Public perceptions and preferences for water services}

Only a few articles were published in 2010 or 2011 on public perceptions and preferences for their water services, three in 2010 (Doria 2010; Lavee 2010; Mugabi, Kayaga et al. 2010) and four in 2011 (Fattahi, Kherikhah et al. 2011; Gebreegziabher and Tadesse 2011; Glenk, Lago et al. 2011; Mendoza 2011). Only one of these articles received any citations by the end of 2011, which was an article on factor influencing public perceptions of drinking water quality (Doria 2010). In terms of geographical focus, these articles were split rough half and half in their focus on either a developed or developing country context.

\section{Integrated water resources management / river basin management / EU Water Framework Directive}

In 2010 there were eight articles dealing with integrated water resources management (IWRM) in some form as their major focus. Three articles (Hearne and Kritsky 2010; Hooper 2010; Larson 2010) dealt with institutional issues relating to IWRM, one article examined water accounting in river basins (Khan, Rana et al. 2010), while four articles related to the EU Water Framework Directive and its implementation (Kanakoudis and Tsitsifli 2010; Stanghellini 2010; van der Veeren 2010; Zanou, Bellas et al. 2010). In 2011, five articles related to IWRM, only one of which on the implementation of the Water Framework Directive (Chen, Maksimovic et al. 2011; Molle and Chu Thai 2011; Uhlendahl, Salian et al. 2011; Wright and Jacobsen 2011; Zhang, Fu et al. 2011). The article by Zhang et al (2011) considered pollution control in the context of IWRM and so could have been classed under the pollution control theme equally as the IWRM theme. Only two of the articles in this theme (Khan, Rana et al. 2010; Wright and Jacobsen 2011) had each been cited once by the end of 2011. It would appear from this sample that focus on the implementation of the Water Framework Directive in the academic literature is declining.

\section{Adaptation to water scarcity}

In 2010 nine papers were published in Water Policy which broadly related to adaptation to water scarcity. Four papers related to improving efficiency of water use or demand management (Burak and Mat 2010; Dollar, Nicolson et al. 2010; Olivier 2010; Saleth and Amarasinghe 2010). The other papers dealt with a range of issues. Ching and $\mathrm{Yu}$ (2010) examined increasing public acceptance of water reuse, while Chang and Boisvert (2010) considered sectorial water transfers. Slaugher et al (2010) considered over-allocation of water resources, while Robinson et al (2010) looked risk management for water shortages of irrigation farmers, and de Castro Lucena Vieira and Rios Ribeiro (2010) discuss first and second-order water conflict analysis relating to water scarcity. In 2011, three 
papers examined sectorial water allocations and re-allocation (Juana, Strzepek et al. 2011; Lennox and Diukanova 2011; Movik 2011). Gerrity and Snyder (2011) examined the economic value of urban water usage in the US, Tarawneh (2011) examined management of a national water supply to cope with drought, Keramitsoglou and Tsagarakis (2011) look at the effectiveness of water saving educational campaigns, while Radulovich (2011) examined potential freshwater savings by increasing human food production in the oceans. These papers relating to adaptation to water scarcity had collectively received six citations by the end of 2011, suggesting that papers on this theme are of above average interest compared to other thematic focuses of water policy.

\section{Improving access to water supply and sanitation}

Ten papers were published in 2010 which related to improving access to water supply and sanitation (WSS) and the fulfilment of the water related Millennium Development Goals. Four papers dealt with rural WSS issues (Anim, Nyame et al. 2010; Biswas and Mandal 2010; Noel, Hoang Thi et al. 2010; Padawangi 2010), and three focused on urban WSS issues (Berg and Mugisha 2010; Kone 2010; Mugisha and Brown 2010). Three papers looked more broadly at a societal level (Kallidaikurichi and Rao 2010; Reddy 2010; Whitford, Smith et al. 2010). Five papers were published on WSS issues in 2011, none of which were focused primarily on just rural or urban WSS issues but considered a broader societal issue, such as van Vliet and Oosterveer (2011) who examined the role of social sciences in improving access to sanitation, Vasquez (2011) who explored official perceptions of municipal water services in Guatemala, Madhoo (2011) who looked at the equity issues resulting from increasing block tariffs, van de Loo (2011) who examined privatisation effects on water access in Kenya, and Mayberry and Baker (2011) who examined the sustainability of small water suppliers in Brazil. Four of the papers published in 2010 and 2011 had been cited by the end of 2011 .

\section{Agricultural water issues}

Water Policy published more papers relating to agricultural water issues than WSS issues during 2010 and 2011, perhaps reflecting the fact that agricultural water use dominates total water use in most societies. In 2010, three papers dealt with participatory management and user associations (Asthana 2010; Bandyopadhyay, Shyamsundar et al. 2010; Gunchinmaa and Yakubov 2010) while the other papers were more diverse in their focus. Narayanamoorthy (2010) examined the sustainability of India's use of groundwater for irrigation, Bartolini et al (2010) used multi-criteria analysis of policy scenarios for Italian irrigated agriculture, Huffaker (2010) examined water use and biofuel production, while Jothiprakash and Mohandoss (2010) at an planning model for a run-of-the-river system, and Palerm-Viqueira (2010) examined historical irrigation water management in Spain and Latin America. In 2011, two papers examined participatory water management (Boyer, Speelman et al. 2011; Kumnerdpet and Sinclair 2011), while three papers related to the efficiency of irrigation water use (Kumar and Palanisami 2011; Qureshi, Grafton et al. 2011; Ramirez, Ward et al. 2011), and three papers discussed decision support systems or modelling tools (Hadihardaja and Grigg 2011; Jothiprakash, Arunkumar et al. 2011; Khan, Rana et al. 2011). Two papers considered water usage and forestry (Keles and Baskent 2011; Nordblom, Reeson et al. 2011), and a paper by Speelman et al (2011) examined irrigation water rights. The agricultural water related papers had received 11 citations by the end of 2011.

\section{Pollution control / preservation of the natural environment}

In 2010 there were two papers published which dealt with the economic value of rivers and water quality (Korsgaard and Schou 2010; Nallathiga and Paravasthu 2010). Two papers focused upon nitrates and phosphates in water (Neset, Drangert et al. 2010; Ngatcha and Daira 2010). A paper by Duane and Opperman (2010) looked at the environmental impacts of water impoundment, and there was one paper looking at impacts of sea level rises on freshwater resources (Gazioglu, Burak et al. 2010). In 2011, Winsten et al (2011) examined agricultural pollution control, Sleasman (2011) considered wastewater management and water quality the Florida Keys areas, while Larson and Stone-Jovicich (2011) examined water quality management in the Great Barrier Reef region of Australia. Shomar (2011) focused upon socio-economic impacts on water resources and the natural environment in the Gaza Strip. There were four citations of papers from 2010 from the thematic issue by the end of 2011 but none from 2011. 


\section{Institutional or regulatory reform}

There were 22 papers published in 2010 and 2011 which related to institutional or regulatory reform in the water sector, a greater number of papers than in any of the other thematic issue categories - a reflection of the fact that this thematic issue relates most directly to water policy development in a general sense. In 2010, four of these papers related to privatisation issues (Adinyira, Sohail et al. 2010; Perard 2010; Schouten and van Dijk 2010; Suleiman and Cars 2010), two papers considered regulatory reform (Asquer 2010; Ehrhardt and Janson 2010) while Araral (2010) conducted a review of water sector reform experiences more broadly. Five papers focused upon regulatory reforms in individual countries: Mapedza and Geheb (2010) reviewed water sector reforms in Zimbabwe, Movik (2011) in South Africa, Tankha and Fuller (2010) in India and Brazil, Luzi (2010) in Egypt and Pearson and Collins (2010) in Australia. In 2011, three papers related to privatisation issues (Asthana 2011; Pezon 2011; Suleiman 2011) and one on regulatory reform (Sanz, Schouten et al. 2011). Five papers examine water policy governance and reform in a specific national context (Barua and van Ast 2011; Carrozza 2011; Gopakumar 2011; Schwartz 2011; Steinman, Nicholas et al. 2011), while a paper by Huitema et al (2011) look policy transmission globally and the role played by policy entrepreneurs. While there were nine citations of the papers published in 2010, none of the 2011 papers had been cited in the academic literature by the end of 2011 .

\section{Discussion and conclusion}

The Water Policy journal aims to publish analyses, reviews and debates on all policy aspects of water resources, while stating that specific examples of topics it publishes on include:

- Ecosystems, engineering, management and restoration

- Engineering and design

- River-basin and watershed management

- Multiple uses of water

- Pollution monitoring and control

- Management, use and sharing of transboundary waters, treaties and allocation agreements

- Capacity building

- Flood control and disaster management

- Groundwater remediation and conjunctive use of groundwater and surface water

- Public participation, consensus building and confidence building

- Conflict management and negotiations of water resources

- Demand management

- Commercialization of water

- Integrated water resources management

- Allocation of risks among stakeholders

(International Water Assocation 2012)

The analysis of two years of papers published in Water Policy show that the journal does publish articles on a wide range of issues relating broadly to water policy. However, the spread of articles published are not well matched to this list of stated topics. Few articles published in Water Policy were focused upon engineering and design, flood control and disaster management, or the allocation of risk among stakeholders. Rather, the journal has tended to publish articles which are more directly linked to water policy, with articles related broadly to institutional and regulatory reform being numerically the most significant in the journal. Examination of the short-term citation rate of articles published did not show a significant bias towards any thematic issue covered by the journal, suggesting interest in a wide range of topics relating to water policy.

Comparing the coverage of issues in 2010 and 2011 there were no marked changes in focus when a qualitative content analysis was conducted. The quantitative content analysis of word frequencies in 
the abstracts and key word lists given by paper authors suggest a slight shift between years, with policy and governance featuring more strongly in 2011 than 2010. Interestingly, sustainability and sustainable development did not directly feature significantly in the water policy articles published, perhaps suggesting that sustainability was seen as inherent to water resources management and WSS issues generally.

\section{References}

Adinyira, E., M. Sohail, et al. (2010). "Private sector driven supply chains in Ghana's rural water sector." Water Policy 12(3): 416-424.

Aguilar-Benitez, I. and J.-D. Saphores (2010). "Public accountability and performance of two border water utilities." Water Policy 12(2): 203-219.

Alam, U., O. Dione, et al. (2011). "Hydrology vs sovereignty: managing the hydrological interdependency of international rivers." Water Policy 13(3): 425-442.

Anim, F., F. K. Nyame, et al. (2010). "Coliform status of water bodies from two districts in Ghana, west Africa: implications for rural water resources management." Water Policy 12(5): 734745.

Araral, E. (2010). "Reform of water institutions: review of evidences and international experiences." Water Policy 12: 8-22.

Asquer, A. (2010). "The regulatory reform of water infrastructure in Italy: overall design and local variations." Water Policy 12: 66-83.

Asthana, A. N. (2010). "Is participatory water management effective? Evidence from Cambodia." Water Policy 12(2): 149-164.

Asthana, V. (2011). "The urban water reform project: a critical discourse analysis of the water policy making process in Delhi, India." Water Policy 13(6): 769-781.

Balthrop, C. and F. Hossain (2010). "Short note: A review of state of the art on treaties in relation to management of transboundary flooding in international river basins and the Global Precipitation Measurement mission." Water Policy 12(5): 635-640.

Bandyopadhyay, S., P. Shyamsundar, et al. (2010). "Transferring irrigation management to farmer's associations: Evidence from the Philippines." Water Policy 12(3): 444-460.

Bartolini, F., V. Gallerani, et al. (2010). "Water management and irrigated agriculture in Italy: multicriteria analysis of alternative policy scenarios." Water Policy 12(1): 135-147.

Barua, S. and J. A. van Ast (2011). "Towards interactive flood management in Dhaka, Bangladesh." Water Policy 13(5): 693-716.

Bearden, B. L. (2010). "The legal regime of the Mekong River: a look back and some proposals for the way ahead." Water Policy 12(6): 798-821.

Berg, S. and R. Marques (2011). "Quantitative studies of water and sanitation utilities: a benchmarking literature survey." Water Policy 13(5): 591-606.

Berg, S. V. and S. Mugisha (2010). "Pro-poor water service strategies in developing countries: promoting justice in Uganda's urban project." Water Policy 12(4): 589-601.

Biswas, P. K. and K. Mandal (2010). "Drinking water in rural India: a study of deficiency, quality and some social implications." Water Policy 12(6): 885-897.

Bleser, C. S. and K. C. Nelson (2011). "Climate change and water governance: an International Joint Commission case study." Water Policy 13(6): 877-894.

Boyer, M., S. Speelman, et al. (2011). "Institutional analysis of irrigation management in Haiti: a case study of three farmer managed schemes." Water Policy 13(4): 555-570.

Burak, S. and H. Mat (2010). "Municipal water demand and efficiency analysis: Case studies in Turkey." Water Policy 12(5): 695-706.

Carrozza, C. (2011). "Italian water services reform from 1994 to 2008: decisional rounds and local modes of governance." Water Policy 13(6): 751-768.

Chang, H.-H. and R. N. Boisvert (2010). "Accounting for the market and non-market values of multifunctional outputs in evaluating water transfers to non-agricultural uses: empirical evidence from Taiwanese rice production." Water Policy 12(4): 528-542. 
Chen, D. C., C. Maksimovic, et al. (2011). "Institutional capacity and policy options for integrated urban water management: a Singapore case study." Water Policy 13(1): 53-68.

Chenoweth, J. (2011). "Will the water resources of Israel, Palestine and Jordan remain sufficient to permit economic and social development for the foreseeable future?" Water Policy 13(3): 397-410.

Ching, L. and D. J. H. Yu (2010). "Turning the tide: informal institutional change in water reuse." Water Policy 12: 121-134.

Chowdhury, N. T. (2010). "Water management in Bangladesh: an analytical review." Water Policy 12(1): 32-51.

Correia, T. and R. C. Marques (2011). "Performance of Portuguese water utilities: how do ownership, size, diversification and vertical integration relate to efficiency?" Water Policy 13(3): 343361.

de Castro Lucena Vieira, Z. M. and M. M. Rios Ribeiro (2010). "A methodology for first- and second-order water conflicts analysis." Water Policy 12(6): 851-870.

De Stefano, L., P. Edwards, et al. (2010). "Tracking cooperation and conflict in international basins: historic and recent trends." Water Policy 12(6): 871-884.

Deutsch, S., J. Schrammel, et al. (2011). Comparing Different Layouts of Tag Clouds: Findings on Visual Perception. 2nd IFIP WG 13.7 Workshop on Human-Computer Interaction and Visualization, Uppsala.

Dollar, E. S. J., C. R. Nicolson, et al. (2010). "Development of the South African Water Resource Classification System (WRCS): a tool towards the sustainable, equitable and efficient use of water resources in a developing country." Water Policy 12(4): 479-499.

Dominguez, D., B. Truffer, et al. (2011). "Tackling uncertainties in infrastructure sectors through strategic planning: the contribution of discursive approaches in the urban water sector." Water Policy 13(3): 299-316.

Doria, M. d. F. (2010). "Factors influencing public perception of drinking water quality." Water Policy 12(1): 1-19.

Duane, T. P. and J. J. Opperman (2010). "Comparing the conservation effectiveness of private water transactions and public policy reforms in the conserving California landscapes initiative." Water Policy 12(6): 913-931.

Easter, K. W. and L. M. J. McCann (2010). "Nested institutions and the need to improve international water institutions." Water Policy 12(4): 500-516.

Egerton, C., R. Santos, et al. (2011). "Cost recovery in times of demographic change: Portugal's domestic water policy." Water Policy 13(3): 326-342.

Ehrhardt, D. and N. Janson (2010). "Can regulation improve the performance of governmentcontrolled water utilities?" Water Policy 12: 23-40.

Fattahi, P., A. Kherikhah, et al. (2011). "An evaluation model for measuring customer satisfaction levels in a water supply domain: case study - water supply in Hamedan." Water Policy 13(4): 490-505.

Ferro, G. and C. A. Romero (2011). "Setting performance standards for regulation of water services: Benchmarking Latin American utilities." Water Policy 13(5): 607-623.

Gazioglu, C., S. Burak, et al. (2010). "Foreseeable impacts of sea level rise on the southern coast of the Marmara Sea (Turkey)." Water Policy 12(6): 932-943.

Gebreegziabher, K. and T. Tadesse (2011). "Household demand for improved water supply services in Mekelle City, Northern Ethiopia." Water Policy 13(1): 125-142.

Gerrity, D. and S. Snyder (2011). "The economic value of water in metropolitan areas of the United States." Water Policy 13(4): 443-458.

Gillham, B. (2005). Research interviewing: The range of techniques. Maidenhead, Open University Press.

Glenk, K., M. Lago, et al. (2011). "Public preferences for water quality improvements: implications for the implementation of the EC Water Framework Directive in Scotland." Water Policy 13(5): 645-662.

Gopakumar, G. (2011). "Policy transmission: the emerging policy dynamic of water supply infrastructure development in India." Water Policy 13(3): 375-392. 
Gunchinmaa, T. and M. Yakubov (2010). "Institutions and transition: does a better institutional environment make water users associations more effective in Central Asia?" Water Policy 12(2): 165-185.

Hadihardaja, I. K. and N. S. Grigg (2011). "Decision support system for irrigation maintenance in Indonesia: a multi-objective optimization study." Water Policy 13(1): 18-27.

Hearne, R. R. and C. C. Kritsky (2010). "Characteristics of active local water management districts in the Red River Basin." Water Policy 12(6): 898-912.

Hooper, B. (2010). "River basin organization performance indicators: application to the Delaware River basin commission." Water Policy 12(4): 461-478.

Huffaker, R. (2010). "Protecting water resources in biofuels production." Water Policy 12(1): 129134.

Huitema, D., L. Lebel, et al. (2011). "The strategies of policy entrepreneurs in water transitions around the world." Water Policy 13(5): 717-733.

International Water Assocation (2012). "Water Policy: The Official Journal of the World Water Council." Retrieved 5 January 2012, 2012, from http://www.iwaponline.com/wp/.

Jothiprakash, V., R. Arunkumar, et al. (2011). "Optimal crop planning using a chance constrained linear programming model." Water Policy 13(5): 734-749.

Jothiprakash, V. and R. Mohandoss (2010). "A weekly operational planning model for a run-off-theriver system: some simulation results from the Tambiraparani river, Tamil Nadu, India." Water Policy 12(3): 318-335.

Juana, J. S., K. M. Strzepek, et al. (2011). "Market efficiency and welfare effects of inter-sectoral water allocation in South Africa." Water Policy 13(2): 220-231.

Judkins, G. L. and K. Larson (2010). "The Yuma desalting plant and Cienega de Santa Clara dispute: a case study review of a workgroup process." Water Policy 12(3): 401-415.

Kallidaikurichi, S. and B. Rao (2010). "Index of drinking water adequacy for the Asian economies." Water Policy 12: 135-154.

Kanakoudis, V. and S. Tsitsifli (2010). "On-going evaluation of the WFD 2000/60/EC implementation process in the European Union, seven years after its launch: are we behind schedule?" Water Policy 12(1): 70-91.

Keles, S. and E. Z. Baskent (2011). "Joint production of timber and water: a case study." Water Policy 13(4): 535-546.

Keramitsoglou, K. M. and K. P. Tsagarakis (2011). "Raising effective awareness for domestic water saving: evidence from an environmental educational programme in Greece." Water Policy 13(6): 828-844.

Khan, S., T. Rana, et al. (2010). "A whole-of-the-catchment water accounting framework to facilitate public private investments: an example from Australia." Water Policy 12(3): 336-356.

Khan, S., T. Rana, et al. (2011). "Decision support model for water policy in the presence of waterlogging and salinity." Water Policy 13(2): 187-207.

Kone, D. (2010). "Making urban excreta and wastewater management contribute to cities' economic development: a paradigm shift." Water Policy 12(4): 602-610.

Korsgaard, L. and J. S. Schou (2010). "Economic valuation of aquatic ecosystem services in developing countries." Water Policy 12(1): 20-31.

Kumar, D. S. and K. Palanisami (2011). "Can drip irrigation technology be socially beneficial? Evidence from Southern India." Water Policy 13(4): 571-587.

Kumar, S. (2010). "Unaccounted for water and the performance of water utilities: an empirical analysis from India." Water Policy 12(5): 707-721.

Kumnerdpet, W. and A. J. Sinclair (2011). "Implementing participatory irrigation management in Thailand." Water Policy 13(2): 265-286.

Larson, S. (2010). "Designing robust water planning institutions in remote regions: a case of Georgina and Diamantina catchment in Australia." Water Policy 12(3): 357-368.

Larson, S. and S. Stone-Jovicich (2011). "Community perceptions of water quality and current institutional arrangements in the Great Barrier Reef Region of Australia." Water Policy 13(3): 411-424. 
Laspidou, C. S., S. E. Gialis, et al. (2011). "Analysis and evaluation of the operational status of municipal wastewater treatment plants in the Dodecanese prefecture in Greece." Water Policy 13(2): 287-297.

Lavee, D. (2010). "Averting expenditures and valuation of damages: two methods for assessing the benefits of water filtration in Israel." Water Policy 12(2): 290-303.

Lennox, J. A. and O. Diukanova (2011). "Modelling regional general equilibrium effects and irrigation in Canterbury." Water Policy 13(2): 250-264.

Luzi, S. (2010). "Driving forces and patterns of water policy making in Egypt." Water Policy 12(1): 92-113.

Madhoo, Y. N. (2011). "Redistributive impact of increasing block residential water rates: some empirical evidence from Mauritius." Water Policy 13(4): 471-489.

Mapedza, E. and K. Geheb (2010). "Power dynamics and water reform in the Zimbabwean context: implications for the poor." Water Policy 12(4): 517-527.

Matthews, B. and L. Ross (2010). Research Methods. Harlow, Pearson Education.

Mayberry, A. L. and T. D. Baker (2011). "Sustainability of small water supplies: lessons from a Brazilian Program (SESP/FSESP)." Water Policy 13(3): 393-396.

Mendoza, R. L. (2011). "Fluoride-treated water and the problem of merit goods." Water Policy 13(1): $38-52$.

Molle, F. and H. Chu Thai (2011). "Implementing integrated river basin management in the Red River Basin, Vietnam: a solution looking for a problem?" Water Policy 13(4): 518-534.

Movik, S. (2011). "Allocation discourses: South African water rights reform." Water Policy 13(2): 161-177.

Mugabi, J., S. Kayaga, et al. (2010). "Determinants of customer decisions to pay utility water bills promptly." Water Policy 12(2): 220-236.

Mugisha, S. and A. Brown (2010). "Patience and action pays: a comparative analysis of WSS reforms in three East African cities." Water Policy 12(5): 654-674.

Nallathiga, R. and R. Paravasthu (2010). "Economic value of conserving river water quality: results from a contingent valuation survey in Yamuna river basin, India." Water Policy 12(2): 260271.

Narayanamoorthy, A. (2010). "India's groundwater irrigation boom: can it be sustained?" Water Policy 12(4): 543-563.

Neset, T.-S. S., J.-O. Drangert, et al. (2010). "Recycling of phosphorus in urban Sweden: a historical overview to guide a strategy for the future." Water Policy 12(4): 611-624.

Ngatcha, B. N. and D. Daira (2010). "Nitrate pollution in groundwater in two selected areas from Cameroon and Chad in the Lake Chad basin." Water Policy 12(5): 722-733.

Noel, S., P. Hoang Thi, et al. (2010). "The impact of domestic water on household enterprises: evidence from Vietnam." Water Policy 12(2): 237-247.

Nordblom, T. L., A. F. Reeson, et al. (2011). "Price discovery and distribution of water rights linking upstream tree plantations to downstream water markets: experiemental results." Water Policy 13(6): 810-827.

OED Online (2011). "Oxford English Dictionary.". Retrieved 4 January 2012, 2012, from http://www.oed.com/.

Olivier, A. (2010). "Water tariffs and consumption drop: an evaluation of households' response to a water tariff increase in Manaus, Brazil." Water Policy 12(4): 564-588.

Padawangi, R. (2010). "Community-driven development as a driver of change: water supply and sanitation projects in rural Punjab, Pakistan." Water Policy 12: 104-120.

Palerm-Viqueira, J. (2010). "A comparative history, from the 16th to 20th centuries, of irrigation water management in Spain, Mexico, Chile, Mendoza (Argentina) and Peru." Water Policy 12(6): 779-797.

Palme, U. (2010). "Multiple conceptions of sustainable urban water systems: problem or asset?" Water Policy 12(3): 425-443.

Pearson, L. J. and K. Collins (2010). "Does social-ecological context influence state-based water management decisions? Case study from Queensland, Australia (1980-2006)." Water Policy 12(2): 186-202. 
Perard, E. (2010). "Private sector participation and regulatory reform in water supply in the Southern Mediterranean region." Water Policy 12: 41-65.

Pezon, C. (2011). "How the Compagnie Generale des Eaux survived the end of concession contracts in France 100 years ago." Water Policy 13(2): 178-186.

Picazo-Tadeo, A. J., F. Saez-Fernandez, et al. (2011). "Assessing performance in the management of the urban water cycle." Water Policy 13(6): 782-796.

Qureshi, M. E., R. Q. Grafton, et al. (2011). "Understanding irrigation water use efficiency at different scales for better policy reform: a case study of the Murray-Darling Basin, Australia." Water Policy 13(1): 1-17.

Radulovich, R. (2011). "Massive freshwater gains from producing food at sea." Water Policy 13(4): 547-554.

Ramirez, O. A., F. A. Ward, et al. (2011). "Efficient water conservation in agriculture for growing urban water demands in Jordan." Water Policy 13(1): 102-124.

Reddy, V. R. (2010). "Water sector performance under scarcity conditions: a case study of Rajasthan, India." Water Policy 12(5): 761-778.

Rieu-Clarke, A. (2010). "The role of treaties in building international watercourse regimes: a legal perspective on existing knowledge." Water Policy 12(6): 822-831.

Robinson, J. R. C., A. M. Michelsen, et al. (2010). "Mitigating water shortages in a multiple risk environment." Water Policy 12(1): 114-128.

Saleth, R. M. and U. A. Amarasinghe (2010). "Promoting irrigation demand management in India: options, linkages and strategy." Water Policy 12(6): 832-850.

Sanz, M. P., M. Schouten, et al. (2011). "Consumer-inclusive economic regulation: water pricing under different regulatory regimes." Water Policy 13(4): 459-470.

Schad, T. M. (1991). "Do we have a national water policy?" Journal of soil and water conservation 46(1): 14-16.

Schouten, M. and M. P. van Dijk (2010). "Regulation and comparative discretion of publicly and privately owned water companies in The Netherlands, England and Wales." Water Policy 12(2): 248-259.

Schwartz, K. (2011). "From government-driven to commercially-driven mergers: changing drivers for upscaling in the Dutch water supply sector." Water Policy 13(3): 317-325.

Shomar, B. (2011). "The Gaza Strip: politics and environment." Water Policy 13(1): 28-37.

Slaughter, R. A., A. F. Hamlet, et al. (2010). "Mandates vs markets: addressing over-allocation of Pacific Northwest River Basins." Water Policy 12(3): 305-317.

Sleasman, K. (2011). "Analysis of wastewater management in the Florida Keys." Water Policy 13(4): 506-517.

Speelman, S., A. Frija, et al. (2011). "The importance of irrigation water rights: lessons from South Africa and Tunisia." Water Policy 13(5): 663-676.

Stanghellini, P. S. L. (2010). "Stakeholder involvement in water management: the role of the stakeholder analysis within participatory processes." Water Policy 12(5): 675-694.

Steinbock, D. (2006). "TagCrowd ". Retrieved 4 January 2012, 2012, from http://tagcrowd.com.

Steinbock, D., P. R, et al. (2007). Wearable Tag Clouds: Visualizations to Facilitate New Collaborations. CSCL 2007: Proceedings of the Conference on Computer Supported Collaborative Learning, New Brunswick, NJ.

Steinman, A. D., J. R. Nicholas, et al. (2011). "Science as a fundamental framework for shaping policy discussions regarding the use of groundwater in the State of Michigan: a case study." Water Policy 13(1): 69-86.

Suleiman, L. (2011). "Civil society: a revived mantra in the development discourse." Water Policy 13(1): 87-101.

Suleiman, L. and G. Cars (2010). "Water supply governance in Accra: "authentic" or "symbolic"." Water Policy 12(2): 272-289.

Tankha, S. and B. Fuller (2010). "Getting things done: bureaucratic and entrepreneurial approaches to the practice of participatory water management reforms in Brazil and India." Water Policy 12: $84-103$.

Tarawneh, Z. S. (2011). "Water supply in Jordan under drought conditions." Water Policy 13(6): 863876. 
Uhlendahl, T., P. Salian, et al. (2011). "Good water governance and IWRM in Zambia: challenges and chances." Water Policy 13(6): 845-862.

van de Loo, E. (2011). "Influence of privatization of water delivery on access to the right to water in Kenya." Water Policy 13(2): 208-219.

van de Watering, C. and A. Neher (2010). "Flood information systems in Europe: a survey of transboundary river management." Water Policy 12(5): 625-634.

van der Brugge, R. and R. de Graaf (2010). "Linking water policy innovation and urban renewal: the case of Rotterdam, The Netherlands." Water Policy 12(3): 381-400.

van der Veeren, R. (2010). "Different cost-benefit analyses in The Netherlands for the European Water Framework Directive." Water Policy 12(5): 746-760.

van Vliet, B. J. M., G. Spaargaren, et al. (2011). "Sanitation under challenge: contributions from the social sciences." Water Policy 13(6): 797-809.

Vasquez, W. F. (2011). "Municipal water services in Guatemala: exploring official perceptions." Water Policy 13(3): 362-374.

Vinnari, E. M. and J. J. Hukka (2010). "An international comparison of the institutional governance of water utility asset management and its implications for Finland." Water Policy 12(1): 52-69.

Whitford, A. B., H. Smith, et al. (2010). "Disparities in access to clean water and sanitation: institutional causes." Water Policy 12: 155-176.

Winsten, J. R., C. Baffaut, et al. (2011). "Performance-based incentives for agricultural pollution control: identifying and assessing performance measures in the United States." Water Policy 13(5): 677-692.

Wright, S. A. L. and B. H. Jacobsen (2011). "Participation in the implementation of the Water Framework Directive in Denmark: The prospects for active involvement." Water Policy 13(2): 232-249.

Zanou, B., C. Bellas, et al. (2010). "Implementation of the European Water Framework Directive: procedures and a simple model for the identification of the most cost-effective measures in eutrophicated catchments." Water Policy 12(3): 369-380.

Zhang, Y., G. Fu, et al. (2011). "Trans-jurisdictional pollution control options within an integrated water resources management framework in water-scarce north-eastern China." Water Policy 13(5): 624-644. 
access analysis basin countries development different institutional irrigation management 1.

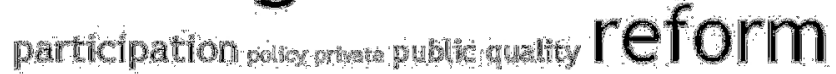
regulation regulatory resources reuss river sanitation sector $_{\text {supply sustainable }}$

Figure 1: Tag cloud of the keywords specified by article authors of all articles published in Water Policy in 2010. (Source: Generated by http://tagcrowd.com ; used with permission) sfrica analysis sast change governance institutions integrated irrigation management model participation policy pollution whines

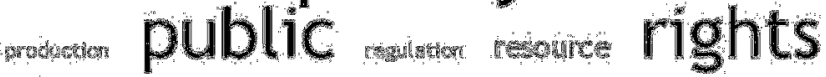
river sobial supply urban utilities wastewater

Figure 2: Tag cloud of the keywords specified by article authors of all articles published in Water Policy in 2011. (Source: Generated by http://tagcrowd.com ; used with permission)

agricultural analysis approach basin context countries demand development different

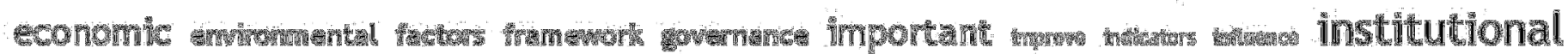
irrigation management paper participatition performance policy private process production pullic quality reforms rogatation

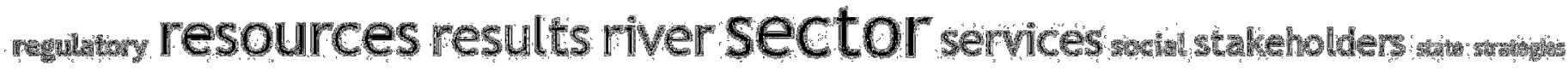
study supplysystem urbanutilities, waw

Figure 3: Tag cloud of the abstracts of all articles published in Water Policy in 2010. (Source: Generated by http://tagcrowd.com ; used with permission)

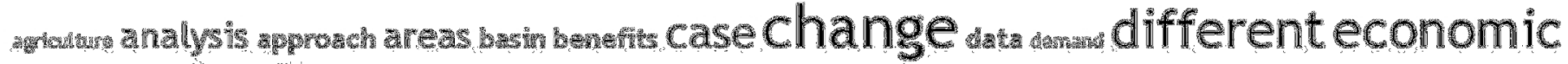
efficiency mirommental governance houstholds increasing institutional irrigation managenent manen

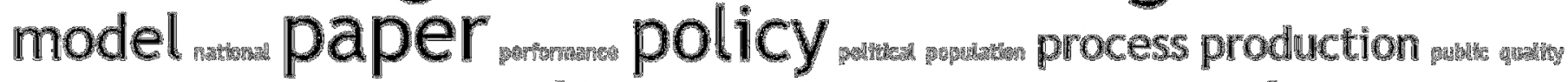
reform reSOURCES results rwer sector services state study supply system willities andues:

Figure 4: Tag cloud of the abstracts of all articles published in Water Policy in 2011. (Source: Generated by http://tagcrowd.com ; used with permission) 